\title{
Points of resistance to Lectio Divina: an anthropological perspective
}

Richard D.G. Irvine

Department of Social Anthropology, University of St Andrews

To appear in CounterText special issue on 'Theologies of Reading'

\begin{abstract}
:
What is distinctive about lectio divina as a practice? What does it require of us, and for what purpose? This ethnographic response considers the relational character of lectio divina and examines the social context of reading as listening. As a way of bringing its characteristics into relief, I describe two ways in which we might find ourselves resisting this slow, prayerful reading. Firstly, the resistance of the body, as it struggles with the physiological challenge of slowing down the pace and recasting reading as an auditory process. Secondly, the resistance of the self, uncomfortable with having to cede control. Lectio divina sits in awkward tension with a world dependent on speed and grounded in individualism.
\end{abstract}

\section{Keywords:}

monasticism; reading; listening; prayer; embodiment; slowness

In the presence of the Rule's invitation to lectio divina - an invitation that grabs hold of us in our sleep and shakes us awake, no less! - it may seem churlish to offer some points of resistance. But I believe that by examining the ways that this form of reading might generate defiance we might bring into relief some of its characteristics as a practice. To that end, I want to briefly discuss two fundamentally interconnected points of resistance: the resistance of the body and the resistance of the self. In doing so, I follow the emphasis on reading as a social practice, while foregrounding the social relation as a site of struggle.

My first sustained encounter with lectio was over the course of the year I spent carrying out ethnographic research with the Benedictine community at Downside Abbey. ${ }^{1}$ I was keen to learn the place of this means of prayer in the life of the community, and it was an element of Benedictine spirituality that monastic communities were keen to present to the wider world through retreats, publications, and so on; for this reason, it seemed like a good starting point for participant

\footnotetext{
${ }^{1}$ I discuss the practice of lectio as part of the social life of the monastery elsewhere (Irvine 2010); this is part of a wider anthropological analysis of the everyday life of monks (Irvine 2017).
} 
observation. What I had not anticipated was the difficulty it would present to me. The slow, prayerful reading of scripture was physiologically hard. Slowing down the pace of reading required constant effort. My eyes would regularly dart beyond the passage that I was reading; looking around the page for context, skipping ahead to get to the point. Rather than coming to rest in the Word of God, as I was being advised to do, my gaze moved restlessly. A prominent sensation in these early days was that of boredom.

The point I wish to draw from this brief reflection on my own preliminary experiences affirms the emphasis on reading as a social process. As Jonathan Boyarin (1989) has argued, we need to pay attention to cultures of readership and to the way that strategies of reading are shaped by the communities of which we are part. Similarly, Eric Livingston (1995: 16), in an anthropological study of the culture of professional literary readers and the learned, routinised skills that allow them to produce critical readings of a text, argues that "Reading is neither in the text nor in the reader. It consists of social phenomena, known through its achievements which lie between the text and the reader's eye, in the reader's implementation of society's means of reading".

Having arrived at the monastery directly from University, and specifically from a number of years dominated by the work of essay writing and compiling literature reviews, the culture of readership in which I was immersed was one which valorised the ability to sift through quantities of material, evaluating the relevance of passages, shifting rapidly within and between texts, and attempting to arrive at some kind of critical response. Indeed, the ability to proceed from undergraduate to $\mathrm{PhD}$ study and then to receive institutional approval to carry out fieldwork was dependent on the implementation of precisely these skills.

Consequently, as I shifted from rapid consumption of mounds of texts to the slow reading of just a short passage, having to hold myself back from skipping ahead to the 'relevant point', the difficulties were not just restricted to the mechanics of reading. Meditatio as a means of listening for the resonance within the text - rather than as a pretext for critical assessment and argumentation also generated resistance, requiring an unlearning of the impulse to prioritise exegesis. 
Entering into a new community of practice involved a re-training of the body. Central to this was the recasting of reading as an auditory process. Deliberate sub-vocalisation - hearing the text as though it was being read to me - radically slowed down the pace of reading while fixing the order of the words, making it difficult to shift around the page at will and restricting the possibility of a 'skim' reading. Correcting my eyes' tendency to skip ahead, I learned instead to return to the start of the passage, over and again, growing in familiarity with the words to which I was listening; a process described to me as "chewing the cud". Such repetition encouraged attention to resonances, nurturing a state of absorption ${ }^{2}$ that led to contemplation beyond the text. As we have seen, such an approach to reading emerges from the social life of the monastery: listening to scripture within the ritual cycle that structures the day, chanting the psalms morning, noon and night, alternately listening to a verse being chanted and then making the next verse sound out in response. At mealtimes too, the monks eat in silence while one of the community reads aloud from a book. In such an environment, to read is to hear. Repetition also emerges from the institutional structure and timetable of community life, returning to the same words, which recur at different points of prayer, and cycle round (at Downside, there was a two-week cycle of psalms over the course of which all 150 psalms were chanted in a set order) such that we are always returning to listen again from the beginning.

As we see, there are resonances here with 'slow reading', and indeed the growth in popular engagement with lectio divina reflected a wider growth of interest in the place of 'slowness', precisely as it strains against rapid cycles of consumption. Wendy Parkins (2004) asks: what kind of spaces for slowness might exist to subvert the cultural dominance of speed? The immediate context for her question is the slow food movement, which has grown from its origins as an organisation set up to resist the opening of a McDonald's restaurant at the Spanish Steps in Rome, to an international organisation and ideal, attempting to re-connect the consumption of food with the local means of production. The points of connection here are not trivial; approaching food in such a way is a reappropriation of the senses (Pink 2007). Bruce Pietrykowski (2004) draws our attention to the work

\footnotetext{
${ }^{2}$ For an anthropological discussion of absorption in prayer, see Luhrmann (2007) on religious experience in American Charismatic Christianity. The significance of repetition in this process also presents opportunity for comparison; see for example Tambiah (1981) on repetition in Theravada Buddhist ritual in Thailand, and Yelle (2003) on Hindu Tantric mantras.
} 
the modifier 'slow' does in re-embedding consumption in social relations; a conscious re-connection with one's own body, with those seated around the table in community with you, and with those who produce that which is about to be consumed.

Here again we return to the point of resistance. Who is able to 'go slow' in this way? Indeed, in the context of time-capitalism, having the scope to spend time so deliberately can be characterised as a form of conspicuous consumption (Veblen 1899), the luxury of leisure. In a sense, this lies at the root of my body's initial resistance to lectio. Paul Saenger (1997) discusses scriptura continua among Irish and Anglo-Saxon monks in the early middle ages; the inscription of texts without spaces between words such that their meaning, consequently, could only be understood through vocalisation. He argues that this needed to give way for the kinds of complex engagement with scholastic texts in the later Middle Ages that simply wouldn't be possible if reading was linked to speech and hearing. These were texts designed to be read discontinuously: "The complex structure of the written page of a fourteenth-century scholastic text presupposed a reader who read only with his eyes, going swiftly from objection to response, from table of contents to the text, from diagram to the text, and from the text to the gloss and its corrections" (1997: 260). From a perspective which emphasises the value of reading as hearing - that of the monastery as a community of listeners - one might argue that an important social dimension of the text is lost here. But in the face of contemporary life, given that rapid individualised ways of reading are considered so essential at a point when we are saturated with texts and lacking time to engage with them, the idea that the text might dictate the pace and the order to the reader seems like a loss of control - and indeed time - that we can ill afford. We are readers in a rush (Caduff 2017), and to forgo speed is to miss out and put oneself at a disadvantage.

This leads us to what I have described above as the resistance of the self. As elucidated in the close reading of the Prologue of the Rule, the social character of reading as listening is, from the outset, understood as a relationship to authority. Maurice Bloch (2004) presents such an approach to religious texts as a form of deference: it is not my intentionality that is important, but the intentionality of the source of the words. He draws on the work of Dale Eickelman (1978) for an example of this process. Eickelman provides an account of the role of memorisation in Islamic learning, which Bloch uses to demonstrate the importance of quotation and repetition by the 
individual learning the Koran: "The student should, ideally, learn the Koran perfectly by heart and so become a totally transparent medium just like Mohamed himself. He should become a sort of tape recorder" (Bloch 2004: 72). It is perhaps telling that Bloch's use of Eickelman here is somewhat restricted: elsewhere, for example, Eickelman (1992) describes how mass education in Oman has created a 'new religious imagination' which emphasises the process of finding meaning and understanding in the text being memorised; here, the displacement of intentionality cannot fully account for the process of learning, and the reader is certainly more than a 'tape recorder'. Nevertheless, what Bloch highlights is the role of power.

In the context of the monastery as a 'school of the Lord's service', scripture is understood to be taking hold of us physically and reshaping us. Merleau-Ponty ([1961] 1994), recognising that vision subjects our body to a world, describes the way the mountain acts upon the painter in the course of painting, and how in turn the viewer of a painting looks according to and with the painting, not just at it. But what is striking, when translated to the monastic context, is that such vision is framed specifically as a ceding of control. Such a challenge sits in uncomfortable friction with individualism as a core value of the wider world in which contemporary Catholic monasticism is situated (Dumont 1992). I draw this point out simply to ask: are we, as readers, prepared for such a loss of autonomy?

The dynamics of reading as a matter of power have been provocatively outlined by Jesper Svenbro (1993) in his study of the way that inscription in Ancient Greece produces speech. His interpretation of the act of reading implied in the texts inscribed on Ancient Greek monuments, with their use of the first person, is that the text appropriates the voice: when reading, the reader's lips "serve an inflexible ego that his not his own" (1993: 36). His depiction recalls Bloch's emphasis on deference, if anything taking it even further: "The reader is, as it were, teleprogrammed: his breath is programmed when he makes the mute grammata sound forth. He puts his vocal apparatus into action as he is programmed to do by the writer. He is the servant of the writing" (1993: 142).

While Svenbro immerses himself in the social life of inscriptions, he nevertheless does so partly in recognition of how dissonant such a depiction is with the modern 'supereader' for whom the 
text "is simply a pretext for a reading that considers itself to be infinitely superior to its object" (1993: 6). With this in mind, I don't think it's far-fetched to say that Svenbro teases his modern readers with the horror of finding themselves wholly at the service of the writer, reduced to an instrument. If such teasing is effective, it is precisely because of the resistance which I have set out here to describe.

Called to listen, we find ourselves in a social relationship that can never be wholly on our own terms; one that occupies our body and that ultimately shapes us for the service of others. In search of resonances, it is perhaps appropriate to give the final word to scripture, at the point where Christ offers Himself to be consumed: "This word is hard; who can hear it?" (John 6:60). 


\section{References}

Bloch, Maurice. 2004. Ritual and Deference. In Ritual and Memory: Toward a Comparative Anthropology of Religion ed. Harvey Whitehouse and James Laidlaw, 65-78. Walnut Creek, CA: Altamira Press.

Boyarin, Jonathan. 1989. Voices around the text: The ethnography of reading at Mesivta Tifereth Jerusalem. Cultural Anthropology 4 (4): 399-421.

Caduff, Carlo. 2017. Speed Crash Course. Cultural Anthropology 32 (1): 12-20.

Dumont, Louis. 1986. Essays on individualism: modern ideology in anthropological perspective. Chicago: University of Chicago Press.

Eickelman, Dale F. 1978. The Art of Memory: Islamic Education and Its Social Reproduction. Comparative Studies in Society and History 20 (4): 485-516.

Eickelman, Dale F. 1992. Mass Higher Education and the Religious Imagination in Contemporary Arab Societies. American Ethnologist 19 (4): 643-655.

Irvine, Richard D.G. 2010. How to read: lectio divina in an English Benedictine monastery. Culture and Religion 11 (4): 395-411.

Irvine, Richard D.G. 2017. The everyday life of monks: English Benedictine identity and the performance of proximity. In Monasticism in Modern Times, ed. Isabelle Jonveaux and Stefania Palmisano, 191-208. London: Routledge.

Livingston, Eric. 1995. An anthropology of reading. Bloomington, IN: Indiana University Press.

Luhrmann, T.M. 2007. How do you learn to know that it is God who speaks? In Learning Religion: Anthropological Approaches ed. David Berliner and Ramon Sarró, 83-102. Oxford: Berghahn.

Merleau-Ponty, Maurice. [1961] 1994. Eye and Mind, trans. Michael B. Smith. In The Merleau-Ponty Aesthetics Reader, ed. Galen A. Johnson, 121-49. Evanston, IL: Northwestern University Press.

Parkins, Wendy. 2004. Out of Time: Fast Subjects and Slow Living. Time and Society 13 (2-3): 363382.

Pietrykowski, Bruce. 2004. You are what you eat: The social economy of the Slow Food movement. Review of Social Economy 62 (3): 307-321.

Pink, Sarah. 2007. Sensing Cittàslow: Slow Living and the Constitution of the Sensory City. The Senses and Society 2 (1): 59-77.

Saenger, Paul. 1997. Space between words: The origins of silent reading. Stanford, CA: Stanford University Press.

Svenbro, Jesper. 1993. Phrasikleia: an anthropology of reading in ancient Greece. Translated by Janet Lloyd. Ithaca, NY: Cornell University Press, 1993.

Tambiah, S.J. 1981. A Performative Approach to Ritual. Proceedings of the British Academy 65: 113169.

Veblen, Thorstein. 1899. The Theory of the Leisure Class: An Economic Study of Institutions. New York: Macmillan.

Yelle, Robert A. 2003. Explaining Mantras: Ritual, Rhetoric, and the Dream of a Natural Language in Hindu Tantra. London: Routledge. 